UNIVERSITE DE LAUSANNE - FACULTE DE BIOLOGIE ET DE MEDECINE

Médecine interne

Physiopathologie clinique

\title{
EVALUATION OF AN ONLINE, CASE-BASED INTERACTIVE APPROACH TO TEACHING PATHOPHYSIOLOGY
}

\section{THESE}

préparée sous la direction du Professeur Bernard Waeber et présentée à la Faculté de biologie et de médecine de l'Université de Lausanne pour l'obtention du grade de

DOCTEUR EN MEDECINE

par

Remco Pieter Canham VAN DIJKEN

Médecin diplômé de la Confédération Suisse

Originaire de Rotterdam (Pays-Bas) 


\section{Rapport de synthèse}

L'article qui fait l'objet de ma thèse évalue une nouvelle approche pédagogique pour l'apprentissage de certains chapitres de physiopathologie. Le dispositif pédagogique se base sur l'alternance d'apprentissage ex-cathedra et de l'utilisation d'un site web comprenant des vignettes cliniques. Lors de la consultation de ces-dernières, l'étudiant est invité à demander des examens de laboratoire dont il pourrait justifier la pertinence selon le cas clinique étudié. La nouveauté du procédé réside dans le fait que, préalablement à son cours ex-cathedra, l'enseignant peut consulter les statistiques de demandes de laboratoire et ainsi orienter son cours selon les éléments mal compris par les étudiants. A la suite du cours ex-cathedra, les étudiants peuvent consulter sur internet la vignettes clinique complète avec des explications.

A l'issue de tout le cours, une évaluation auprès des étudiants a été conduite. Le procédé a été mis en place durant deux années consécutives et l'article en discute notamment les résultats. Nous avons pu conclure que cette méthode innovatrice d'enseignement amène les étudiants à mieux se préparer pour les cours ex-cathedra tout en permettant à l'enseignant d'identifier plus précisément quelles thématiques étaient difficiles pour les étudiants et donc d'ajuster au mieux son cours.

Mon travail de thèse a consisté à créer ce dispositif d'apprentissage, à créer l'application web des vignettes cliniques et à l'implanter durant deux années consécutives. J'ai ensuite analysé les données des évaluations et écrit l'article que j'ai présenté à la revue 'Medical Teacher'. Après quelques corrections et précisions demandées par le comité de lecture, l'article a été accepté et publié.

Ce travail a débouché sur une seconde version de l'application web qui est actuellement utilisée lors du module 3.1 de 3è année à l'Ecole de Médecine à Lausanne.

Lausanne, le 15 janvier 2009

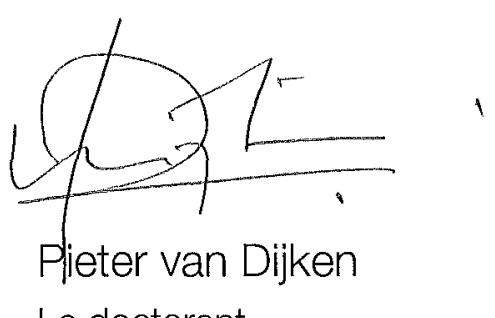

Le doctorant 


\title{
Evaluation of an online, case-based interactive approach to teaching pathophysiology
}

\author{
PIETER CANHAM VAN DIJKEN ${ }^{\dagger}$, SARA THÉVOZ ${ }^{1}$, PATRICK JUCKER-KUPPER ${ }^{\dagger}$, FRANCOIS FEIHL ${ }^{2}$, \\ RAPHAËL BONVIN ${ }^{+}$\& BERNARD WAEBER ${ }^{1,2}$ \\ ${ }^{1}$ Medical Education Unit, Faculy of Biology and Medicine, ${ }^{2}$ Division of Clnical Pathophysiology, Department of Internal \\ Medicine, University Hospltal, Lausame, Swizerland
}

\section{Abstract}

Aim: The aim of this study was to evaluate a new pedagogical approach in teaching fluid, electrolyte and acid-base pathophysiology in undergraduate students.

Methods: This approach comprises traditional lectures, the study of clinical cases on the web and a final interactive discussion of these cases in the classroom. When on the web, the students are asked to select laboratory tests that seem most appropriate to understand the pathophysiological condition underlying the clinical case. The percentage of students having chosen a given test is made available to the teacher who uses it in an interactive session to stimulate discussion with the whole class of students. The same teacher used the same case studies during 2 consecutive years during the third year of the curriculum.

Results: The majority of students answered the questions on the web as requested and evaluated positively their experience with this form of teaching and learning.

Conclusions: Complementing traditional lectures with online case-based studies and interactive group discussions represents, therefore, a simple means to promote the learning and the understanding of complex pathophysiological mechanisms. This simple problem-based approach to teaching and learning may be implemented to cover all fields of medicine.

\section{Background}

The use of the web in medical education is very attractive for both students and educators (Chumley-Jones et al. 2002; McKimm et al. 2003). This communication technology is now widely available and offers the opportunity to introduce computer-assisted instructional programs into the curriculum of medical schools. Web-based learning (WBL) may replace face-to-face teaching, allowing the maximization of institutional resources since a given course can be delivered online to a large number of students. It may also be used as a support to conventional teaching, with the aim to encourage more independent and active learning. WBL has not only advantages and is not necessarily superior to traditional teaching methods (Friedman 1996; McKimm et al. 2003). A number of principles should be taken into account for developing effective WBL (Cook \& Dupras 1994). Among these principles, it is worth mentioning the definition of specific goals and objectives, the incentive for self-directed, problem-based and interactive learning, as well as the design of easy to use programs. With this is in mind we conceived a new e-learning tool to be used as a complement to a traditional lecture course in pathophysiology.

Case-based leaming (CBL) represents another way to facilitate the learning process of students. Its main advantage is to link theoretical concepts and clinical situations to be solved, allowing medical students to take better advantage of their grounding in basic sciences to solve complex patient-
Praclice points

A web based interaction with the students prior to a classroom lecture enhances their active participation during the lecture.

- The study of clinical cases on the web linked to an online activity (choosing lab tests) promotes a deeper forethought of the case.

The fact that the lecturer knows decisions made by students facing a clinical case, before the classroom lecture, helps him to understand their way of thinking and subsequently to drive the discussion during the face-to face teaching.

oriented problems. CBL promotes hypothesis generalization, consolidation and integration of learning activities and contributes to develop team working skills (Williams 2005).

Pathophysiology is the discipline focusing on the physiological and biological manifestations of disease and the adaptations that the body makes to the changes produced by the disease process. Altered fluid, electrolyte and acid-base balance represents an area of pathophysiology that is particularly difficult to master by medical students as it implies complex integrative regulatory mechanisms involving different organs. In the Faculty of Biology and Medicine of Lausanne pathophysiology has been taught for many years during the third year by classroom lectures. 


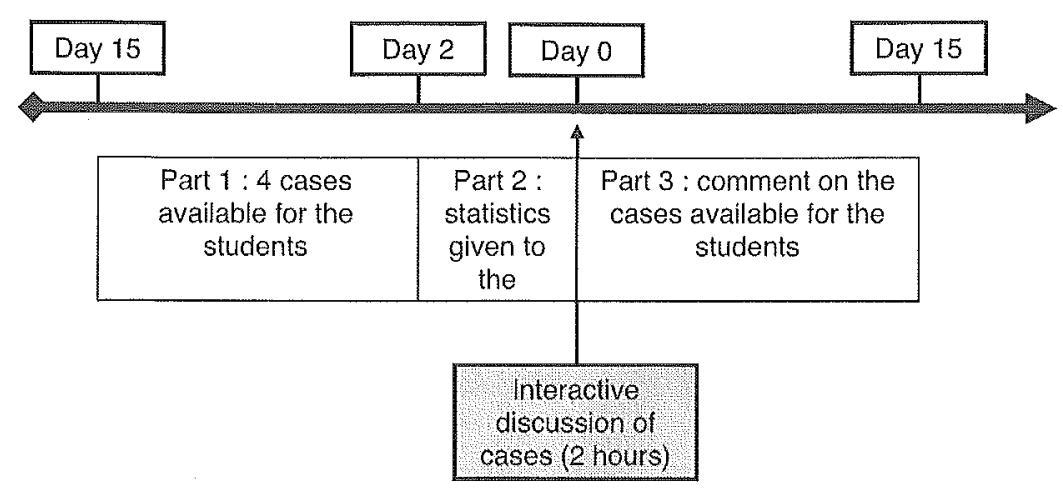

Figure 1. Procedure.

\section{Aims}

The aim of this paper is first to describe the patient-based, WBL program that we created to help students to better understand and interpret the clinical and laboratory findings associated with disorders in fluid, electrolyte and acid-base homeostasis. Another aim is to comment the feedback of students we obtained on our online, interactive support of traditional teaching. Finally, this paper is also directed to share our positive experience with this pedagogical set up and make freely available the software we developed for all teachers who would like to use it.

\section{Methods}

In the Faculty of Biology and Medicine of Lausanne medical students are exposed to didactic lectures covering all fields of pathophysiology during the third year of the curriculum. Eleven hours are directed to the teaching of fluid, electrolyte and acid-base disorders, under the responsibility of the same lecturer (BW). A summative exam (multiple choice questions) is performed at the end of the academic year to test the students' knowledge.

The last 2 hours of the pathophysiology course are dedicated to an interactive discussion based on clinical cases (referred to below as 'interactive session'). The students are invited to prepare this discussion by studying the cases on the web. The procedure comprises 3 parts (Figure 1).

Part 1: The clinical history of 4 patients is made available on the students' website 15 days before conducting the interactive session. The cases are chosen to be representative of typical fluid, electrolyte and acid-basic disturbances encountered in clinical practice (diarrhea-induced hypernatremia and metabolic acidosis, vomiting-induced metabolic alkalosis, hyperosmolar diabetic coma, diabetic ketoacidosis). A list of 33 laboratory tests (in blood and urine) is proposed. The students are asked to select the tests that seem the most appropriate to understand the path physiological condition underlying the clinical case. The results of tests preselected by the teacher are immediately provided whereas no result is given for the tests considered as non-essential. The students have the opportunity to print the cases together with the laboratory results.

Part 2: Two days before the interactive session, the administrator of the website (PCvD) closes the site and switches on the automatic calculation of the number of students who studied each case, and the percentage of them who have asked for each laboratory test. This analysis is made available to the teacher on the day before the plenary session, allowing him the interactive resolution of clinical cases by asking students questions such as: «Why did you ask for this test? », « How do you interpret the result of this test? », «How do you explain the development of the observed abnormalities? », This also makes it possible for the teacher to comment on the answers given by the students on the web.

Part 3: The resolution of cases is provided on the students' website for 15 days after the interactive session.

An evaluation form was administered to the students at the end of the interactive session. The students were asked whether or not they used the online program. They were also instructed on how to fill the forms by selecting for each question (Table 1) a response on a Likert scale (« Strongly agree », «Agree », « Disagree », « Strongly disagree » or «Unknown»). Open-ended free comments were also solicited. The analysis of evaluation forms was carried-out in an anonymous fashion by a collaborator of the Educational Unit (ST). Free comments were counted and classified as expressing either a positive or a negative judgment on one aspect or another. The number of positive and negative comments was then calculated. The evaluation of our new online, case-based approach to teaching has been carried-out during two consecutive academic years [2004-2005 (Year 1) and 2005-2006 (Year 2)]. The statistical comparison between the two sets of observations was made using a Mann-Whitney test. A p value $<0.05$ was considered significant.

The software has been developed by PCVD and uses PHP as programming language and MySQL as Database, both wide spread open-source web technologies.

The cases are stored in an $x \mathrm{ml}$ file quick creation and update of the cases without programming knowledge. Only a few XML tags must be known. The software is made available free of charge on the web (http://cases.2bib.ch). 


\begin{tabular}{|c|c|c|c|c|c|c|}
\hline & & \multicolumn{2}{|c|}{ Year 1} & \multicolumn{2}{|c|}{ Year 2} & \multirow[b]{2}{*}{ p } \\
\hline & & $n$ & $\%$ & n & $\%$ & \\
\hline \multirow[t]{3}{*}{ (1) } & Did you ask for laboratory tests as requested? & & & & & ns \\
\hline & Yes & 44 & 83 & 73 & 91.3 & \\
\hline & No & 9 & 17 & 7 & 8.7 & \\
\hline \multirow[t]{3}{*}{ (2) } & Did you print the case studies? & & & & & 0.013 \\
\hline & Yes & 39 & 73.6 & 41 & 51.2 & \\
\hline & No & 14 & 26.4 & 38 & 47.5 & \\
\hline \multirow[t]{6}{*}{ (3) } & Was the work on internet stimulating? & & & & & 0.004 \\
\hline & Strongly agree & 23 & 43.4 & 57 & 71.3 & \\
\hline & Agree & 23 & 43.4 & 18 & 22.5 & \\
\hline & Disagree & 4 & 7.5 & 2 & 2.4 & \\
\hline & Strongly disagree & 1 & 1.9 & 1 & 1.3 & \\
\hline & Unknown & 2 & 3.8 & 2 & 2.4 & \\
\hline \multirow[t]{6}{*}{ (4) } & Did the work on internet motivate you to independent learning? & & & & & $\mathrm{ns}$ \\
\hline & Strongly agree & 22 & 41.5 & 31 & 38.8 & \\
\hline & Agree & 18 & 34.0 & 33 & 41.3 & \\
\hline & Disagree & 6 & 11.3 & 11 & 13.7 & \\
\hline & Strongly disagree & 5 & 9.4 & 5 & 6.2 & \\
\hline & Unknown & 1 & 1.9 & 0 & 0 & \\
\hline \multirow[t]{6}{*}{ (5) } & $\begin{array}{l}\text { Was the case preparation on internet useful for understanding the } \\
\text { clinical significance of laboratory tests? }\end{array}$ & & & & & ns \\
\hline & Strongly agree & 16 & 30.3 & 23 & 28.7 & \\
\hline & Agree & 28 & 52.8 & 47 & 58.8 & \\
\hline & Disagree & 4 & 7.5 & 4 & 5.0 & \\
\hline & Strongly disagree & 0 & 0 & 0 & 0 & \\
\hline & Unknown & 5 & 9.4 & 6 & 7.5 & \\
\hline \multirow[t]{6}{*}{ (6) } & Was the complexity of the clinical cases appropriate for your knowledge? & & & & & ns \\
\hline & Strongly agree & 17 & 32.1 & 31 & 38.8 & \\
\hline & Agrea & 29 & 54.7 & 46 & 57.5 & \\
\hline & Disagree & 3 & 5.7 & 1 & 1.3 & \\
\hline & Strongly disagree & 2 & 3.7 & 0 & 0 & \\
\hline & Unknown & 2 & 3.7 & 2 & 2.4 & \\
\hline \multirow[t]{6}{*}{ (7) } & Were the online procedures easy to follow? & & & & & ns \\
\hline & Strongly agree & 41 & 77.4 & 70 & 87.5 & \\
\hline & Agree & 10 & 18.9 & 9 & 11.3 & \\
\hline & Disagree & 1 & 1.8 & 0 & 0 & \\
\hline & Strongly disagree & 0 & 0 & 1 & 1.2 & \\
\hline & Unknown & 1 & 1.8 & 0 & 0 & \\
\hline
\end{tabular}

PCvD can be contacted at the e-mail address whenever assistance is required

\section{Results}

The number of students having to attend the pathophysiology course during the third year of the curriculum was 120 and 122 during Year 1 and Year 2, respectively. Table 2 gives the number of students who visited the website to discover the four patient cases during each of the two years. The first line relates to the average number of real visits as recorded by the web server. This number was slightly greater that the one based on the evaluation form, which might be accounted for by the fact that students visiting the website did not necessarily fill up the evaluation forms. Actually, the number of evaluation forms collected was 78 for year 1 and 95 for year 2 . The response rate, calculated in taking into account all registered students, was therefore $65 \%$ during Year 1 and $78 \%$ during Year 2. Out of the students who completed the form, $68 \%(53 / 78)$ went through the web case-stories during
Year 1, compared with $84 \%$ (80/95) during Year 2. The MannWhitney test performed showed that this difference is significant ( $\left.p^{1 / 4} 0.010\right)$.

Table 1 shows the percentage of the ratings given by the students who went on the web. By far the majority of students gave a «Strongly agree» or «Agree» rating. This was true for all questions, and the ratings were very similar on Year 1 and Year 2. Nevertheless the answers to two questions were significantly different: the students of Year 2 printed more often the case studies ( $p 1 / 40.013)$ and were more stimulated by the work on internet $\left(p^{1 / 4} 0.004\right)$ than the students of Year 1. For all the other questions the results were not significantly different on Year 1 and Year 2.

The worst rating including « Strongly agree» and " Agree " answers achieved $75.5 \%$ during Year 1 and $80.1 \%$ during Year 2, and dealt with the question: «Did the work on internet motivate you to independent learning? ». The best rating, according to the same criteria, corresponded to the question: "Were the online procedures easy to follow? $\gg$ and reached $96.3 \%$ and $98.8 \%$ during Year 1 and Year 2 , respectively. 
When asked « Was the interactive session really interactive? 》 and « Did you enjoy the interactive session? 》 nearly all students answered « Strongly agree» or « Agree », regardless of the fact they studied or not the case stories on the web. This is illustrated in Figure 2.

There were a total of 85 and 82 spontaneous, hand-written comments in the Year 1 and Year 2 evaluations, respectively (Table 3). There were more positive (n $1 / 459$ Year 1 , and $n 1 / 461$ Year 2) than negative comments ( $n 1 / 414$ Year 1 , and $n 1 / 414$ Year 2). Most of the positive comments stressed that the approach was clinically oriented (n1/419 Year 1 , and $n 1 / 432$ Year 2) and pointed out that the pedagogical scenario was stimulating (n1/411 Year 1 , and $n 1 / 415$ Year 2).

\section{Conclusions}

In clinical practice, an understanding of the mechanisms of diseases is a pivotal part of the evaluation of patients. Case-based teaching represents an effective way to bridge the gap between theory and practice, allowing medical students to take better advantage of their grounding in basic sciences to solve complex patient-oriented problems.

\begin{tabular}{|c|c|c|c|c|c|}
\hline & \multicolumn{2}{|c|}{ Year 1} & \multicolumn{2}{|c|}{ Year 2} & \multirow[b]{2}{*}{$\mathrm{p}$} \\
\hline & n & $\%$ & $\pi$ & $\%$ & \\
\hline $\begin{array}{l}\text { 1. Students who visited the website (count based } \\
\text { on web server statislics) }\end{array}$ & $66.5^{*}$ & - & $94.75^{\star}$ & - & \\
\hline $\begin{array}{l}\text { 2. Students who visited the website (count based } \\
\text { on the evaluation form) }\end{array}$ & 53 & 67.9 & 80 & 84.2 & \\
\hline 3. Students who didn't visit the website & 25 & 32.1 & 15 & 15.8 & \\
\hline Total of $2 \mathrm{p} 3$ & 78 & 100 & 95 & 100 & 0.01 \\
\hline
\end{tabular}

*Represents the average of visits recorded by the wab server for the 4 cases that were analysed.

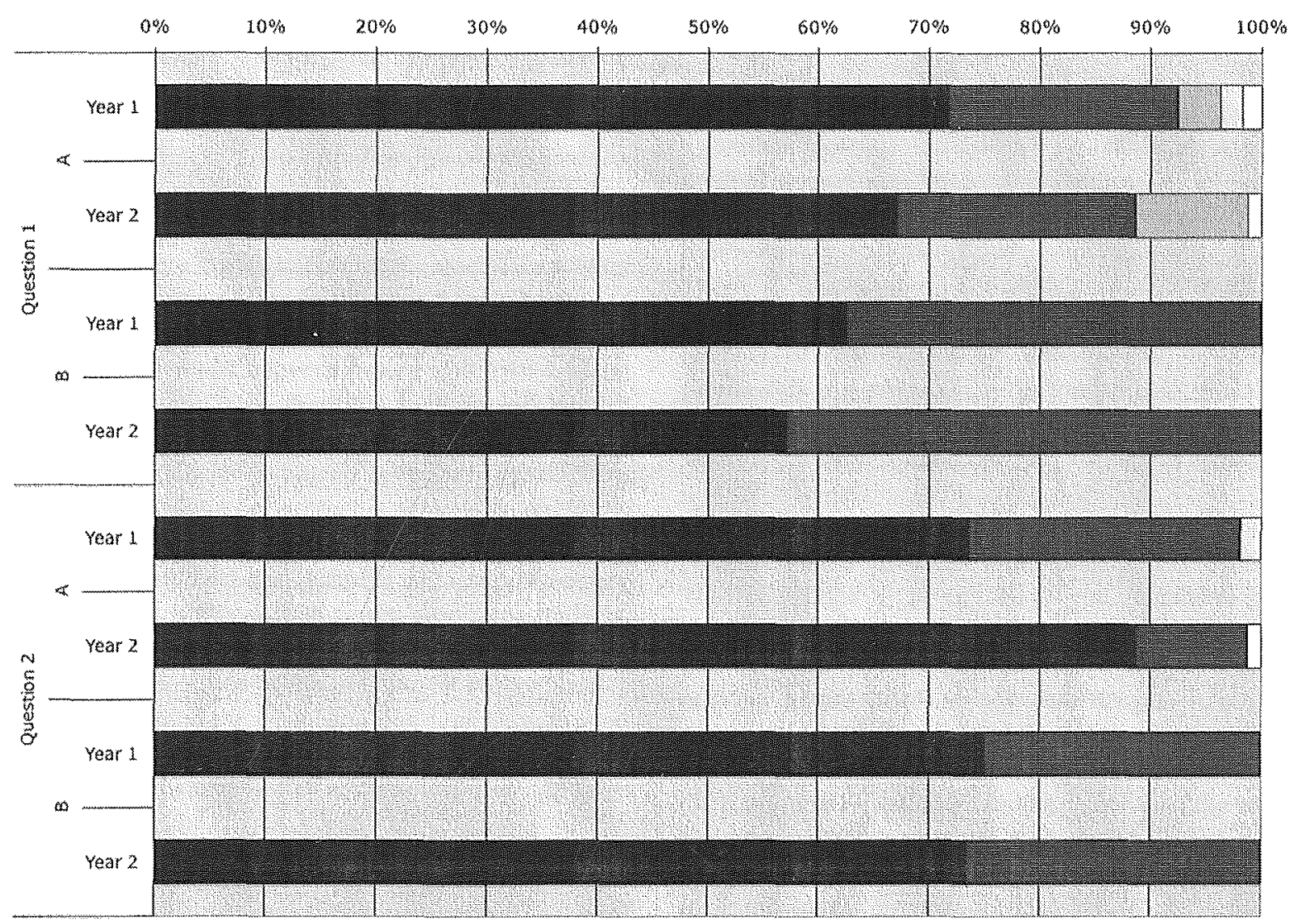

Strongly agree Agree Disagree $\square$ Strongly disagree Dunknown

Figure 2. Fractions of students having answered by «Strongly agree », « Agree», « Disagree», « Strongly disagree » or «Unknown », to the questions « Was the interactive session really interactive ? (Question 1) and « Did you enjoy the interactive session? » (Question 2). In A are shown the answers of students who have experienced the e-learning and in B those of students who did not study the cases on the web. 
Positive experience with case-based teaching tutorials in the field of cardiovascular physiology has been reported (Hudson et al. 2001). This teaching was performed in small groups of students with a tutor as a facilitator of the learning process. We recently developed a web case-based teaching of fluid, electrolyte and acid-base homeostasis disorders. This teaching approach has also as objectives, like the case-based teaching tutorials described by Hudson et al. (2001), « to foster an understanding of the elements of history, physical examination, and investigation in a casebased learning environment » and « to strengthen problem solving and problem-based learning skills ». Our concept is however original in important aspects: (1) the clinical cases are made available on the web a few days before conducting an interactive session; (2) the interactive session involves the entire classroom under the supervision of a teacher who prepared the case studies as a complement to his didactic lectures; (3) the teacher receives online a feedback of students before the interactive session.

Our online case-based teaching approach has one main advantage: it represents not only an ont-of-class lecture aid, but also an incentive for independent work. Furthermore, it allows the challenging of students and the getting of an anonymous feedback to stimulate student-teacher discussions on the day of the interactive session. Our concept is different from that of other teachers who used the web as a discussion forum as a supplement of a traditional physiology course (Taradi \& Taradi 2004). It is more like the interactive webbased rheumatology teaching developed recently for undergraduate students and based on the presentation of clinical cases (Wilson et al. 2006), but in our approach, the students receive an immediate, online feedback on the options they took when they went through the case.

Our students were invited to prepare the discussion session by completing the case studies on the web. A large fraction of them did so (Year 1: 67.9\%; Year 2: 84.2\%; p 1/40.010). The significant difference between Year 1 and Year 2 could be explained by the fact that the students of Year 1 recommended the site to their colleagues of Year 2. The reason(s) why the remaining students did not explore this new teaching resource was unfortunately not explored in our study. To be considered is a lack of motivation, possibly because solving the case studies was regarded as a supplementary «homework» which was not mandatory. Also some students, possibly had no easy access to the web at home, even if internet access is provided in the institutional library. Among students who returned the evaluation questionnaires, around $80 \%$ navigated through the cases and ordered laboratory tests as requested. Approximately $40 \%$ of these web users said that

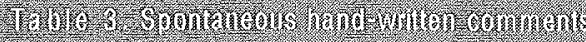

\begin{tabular}{|c|c|c|c|c|}
\hline & \multicolumn{2}{|c|}{ Year 1} & \multicolumn{2}{|c|}{ Year 2} \\
\hline & n & $\%$ & $n$ & $\%$ \\
\hline Positive comments & 59 & 69.4 & 61 & 74.4 \\
\hline Negative comments & 14 & 16.5 & 14 & 17.1 \\
\hline
\end{tabular}

this led them to prepare the interactive session, on both Year 1 and Year 2.

The responses to the questionnaire were similarly positive on the two consecutive years. More or less $90 \%$ of students agreed that working on the cases online was stimulating

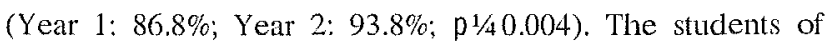
Year 2 were significantly more stimulated than the students of Year 1 but more than $85 \%$ of students were satisfied on both years. An explanation could be that we encouraged the students probably more during the second year. The students agreed that the task to choose the most appropriate tests was useful and that the complexity of the clinical cases corresponded to their degree of knowledge. A main objective of our web-teaching program was to motivate students to deepen their knowledge. This goal was indeed achieved in $80 \%$ of students. Moreover, more than $90 \%$ of students found that the online program was easy to use. The stimulating aspect of this method is supported by the free comments made by the students. Finally, the students pointed out through their free comments the practical feature of the approach. They appreciated having the opportunity of applying the learned theory to clinical cases.

The interactive session was highly appreciated by the students. This last step of our case-based problem solving approach was appreciated regardless of whether the students participated or not in the initial step on the web. Notably, the teacher had available on the day of the interactive session information on how students ordered investigations during the online case studies. This was felt by the teacher to be of great help in promoting questions and answers from the class.

Problem-solving learning is an essential approach in medical education as it enhances the ability of students to apply their knowledge in solving problems, which will represent a main task in their future professional activities. The study of clinical cases is particularly suitable for this type of active learning (Schuwirth et al. 2001). The use of blended learning of pathophysiology described in this paper had presumably a positive effect on the learning process of our students. This remains however uncertain as we did not assess whether completing the proposed case studies on the web had a positive impact on the learning outcome.

A few years ago Rawson \& Quilan (2002) developed a computer-based approach to teaching acid/base physiology. They concluded by proposing general guidelines for educational software development. According to these reconmendations, our case-based learning concept should well respond to the needs of the students: (1) it uses clinical cases; (2) it repeats concepts in a variety of contexts (lectures, self-training on the web, interactive discussion); (3) it promotes the understanding rather than the memorization process; (4) it provides a means to discuss why some answers are wrong and why the right answer is correct; (5) it provides a direction for learning; (6) the software is of easy use. Finally, major advantages of our approach are to allow the student to prepare himself for the interactive session and the teacher to drive his teaching by knowing in advance the performance of the students prior to the interactive session, thereby stimulating the discussion; often difficult in a large group of students. 
In conclusion, the present study describes a new approach to teaching pathophysiology, which includes traditional lectures, individual studies of clinical cases on the web, and interactive student-teacher discussions. In our opinion, our approach is innovative as it allows the student to prepare himself before a lecture, facilitating thereby the interaction with the teacher, and the teacher to drive his lecture in taking into account the answers given by the students on the web. This teaching approach, overall, was very well perceived by the students, which urges us to extend it's use in the curriculum during the coming years.

Although very promising, this approach still needs to be validated by comparing the performance of students who used this set up with the one of those who did not.

\section{Notes on contributors}

PIETER CANHAM VAN DIJKEN is the c-learning coordinator at the medical education unit of the Medical School of the Faculty of Biology and Medicine of Lausanne, Switzerland. He is an MD and has developed several programs for c-learning.

SARA THEVOZ is a psychologist and is the person responsible for the cvaluation of teaching at the pedagogical unit of the Medical School of the Faculty of Biology and Medicine of Lausanne, Switzerland. She contributed to the statistical analysis of this manuscript.

PATRICK JUCKER-KUPPER is an MD and has developed content for various e-learning projects. His research interests include pedagogical approaches of information retricval, multilingual terminology and e-learning in gencral.

FRANCCOIS FEIHL is an MD and an instructor in Pathophysiology at the Medical School of the Faculty of Biology and Medicine of Lausanne, Switzerland. His research interests center on the pathophysiology of septic shock.
RAPHAËL BONVIN is Director of the medical education unit at the Medical School of the Faculty of Biology and Medicine of Lausanne, Switzerland. He is an MD and trained in internal medicine and in medical education.

BERNARD WAEBER is Professor of Pathophysiology at the Medical School of the Faculty of Biology and Medicine of Lausanne, Switzerland. His main interests in research are cardiovascular field and medical education.

\section{References}

Chumley-Jones HS, Dobbie A, Alford CL. 2002. Web-based learning: sound educational method or hype? A review of the cvaluation literature. Acal Med 77:86-93.

Cook DA, Dupras DM. 2004. A practical guide to developing effectivo web-based learning, J Gene Intern Med 19:698-707.

Friedman RB. 1996. Top ten reasons the World Wide Web may fail to change medical education. Acad Medicine 71:979-981.

Hudson JN, Buckley P, McMillen IC. 2001. Linking cardiovascular theory to practice in an undergraduate medical curriculum. Advan Physiol Educ 25:193-201.

McKimm J, Jollie C, Cantillon P. 2003. ABC of learning and teaching: web based learning. BMJ (Clinical Research ed.) 326:870-873.

Rawson RE, Quinlan KM. 2002. Evaluation of a computer-based approach to teaching acid/basc physiology. Advan Plysiol Educ 26:85-97.

Schuwirth LW, Verheggen MM, van der Vleuten CP, Boshuizen HP, Dinant GJ. 2001. Do short cases elicit different thinking processes than factual knowledge questions do? Med Educ 35:348-356.

Taradi SK, Taradi M. 2004. Expanding the traditional physiology class with asynchronous online discussions and collaborative projects. Advan Physiol Educ 28:73-78.

Williams B. 2005. Case basd learning - a review of the litcrature: is there scope for this educational paradigm in prehospital education? Emerg Med J 22:577-581.

Wilson AS, Goodall JE, Ambrosini G, Carruthers DM, Chan H, Ong SG, Gordon C, Young SP. (2006) Development of an interactive learning tool for tcaching rheumatology-a simulated clinical case studies program. Rheumatol (Oxford, England), 45: 1158-1161. 